\title{
COMMENTS ON “A SYSTEMATIC REVIEW OF ALUMINIUM PHOSPHIDE POISONING”
}

\author{
Zeynab NASRI NASRABADI ${ }^{1}$ and Sayed Mahdi MARASHI ${ }^{2}$
}

\begin{abstract}
Department of Pediatrics, Children's Medical Center, Pediatric Center of Excellence, Tehran University of Medical Sciences ${ }^{1}$, Department of Forensic Medicine and Toxicology, Tehran University of Medical Sciences ${ }^{2}$,Tehran, Iran
\end{abstract}

We have read with curiosity the systematic review of aluminium phosphide poisoning by Mehrpour et al. (1) recently published in the Archives of Industrial Hygiene and Toxicology. They mentioned potassium permanganate (1:10,000 solution) as an option in the management of aluminium phosphide toxicity and claimed that it can oxidise phosphine gas in the stomach to phosphate, and therefore decrease the quantity of lethal phosphine gas. Here the authors cite two case reports using potassium permanganate $(1: 10,000$ solution) without any strong scientific basis $(2,3)$.

As we know, in contact with mucus potassium permanganate $\left(\mathrm{KMnO}_{4}\right)$ forms manganese dioxide, potassium hydroxide, and free oxygen radical. Therefore it can lead to systemic toxicity itself (4). Because of its weak bonds with the aluminium-based compound, phosphine gas $\left(\mathrm{PH}_{3}\right)$ can easily be released after ingestion (5). $\mathrm{PH}_{3}$ is a hard nucleophile (species with increased electron density over a small area) and therefore tends to react with hard electrophiles $(4,6)$, but phosphine, the small nucleophile, and free oxygen radical, another small nucleophile, do not interact with each other.

The only clinical indication for potassium permanganate prescription may be white phosphorus $\left(\mathrm{P}_{4}\right)$ ingestion, as it converts it to a less destructive oxide compound. However, due to its chemical properties, clinicians should be aware of the risk of systemic toxicity. In addition, no clinical trials have yet determined its risk-to-benefit profile (4).

We think that prescribing potassium permanganate in aluminium phosphide poisoning stems from an ancient misperception of the chemical structure of phosphine $\left(\mathrm{PH}_{3}\right)$ versus white phosphorus $\left(\mathrm{P}_{4}\right)$.

\section{REFERENCES}

1. Mehrpour O, Jafarzadeh M, Abdollahi M. A systematic review of aluminum phosphide poisoning. Arh Hig Rada Toksikol 2012;63:61-73.

2. Shadnia S, Rahimi M, Pajoumand A, Rasouli MH, Abdollahi M. Successful treatment of acute aluminium phosphide poisoning: possible benefit of coconut oil. Hum Exp Toxicol 2005;24:215-8.

3. Pajoumand A, Jalali N, Abdollahi M, Shadnia S. Survival following severe aluminum phosphide poisoning. J Pharm Pract Res 2002;32:297-9.

4. Hoffman RS, Nelson LS, Howland MA, Levin NA, Flomenbaum NE, Goldfrank LR. Goldfrank's Manual of Toxicologic Emergencies. New York (NY): McGraw Hill Publishing; 2007.

5. Chen S, Li J, Zhou C, Wu J, Tempel DJ, Henderson PB, Brzozowski JR, Cheng H. Weak chemical complexation of $\mathrm{PH}_{3}$ with ionic liquids. J Phys Chem B 2010;114:904-9.

6. Brönstrup M, Schröder D, Schwarz H. Platinum-mediated coupling of methane and small nucleophiles $\left(\mathrm{H}_{2} \mathrm{O}, \mathrm{PH}_{3}, \mathrm{H}_{2} \mathrm{~S}\right.$, $\mathrm{CH}_{3} \mathrm{NH}_{2}$ ) as a model for $\mathrm{C}-\mathrm{N}, \mathrm{C}-\mathrm{O}, \mathrm{C}-\mathrm{P}$, and $\mathrm{C}-\mathrm{S}$ bond formation in the gas phase. Organometallics 1999;18:193948.

\section{CORRESPONDING AUTHOR:}

Sayed Mahdi Marashi

Department of Forensic Medicine and Toxicology

Tehran University of Medical Sciences

16 Azar Avenue, Tehran, Iran

E-mail:marashi_m@razi.tums.ac.ir 